\title{
USAHATANI, PENDAPATAN DAN KESEJAHTERAAN PETANI KOPI DI LAMPUNG BARAT
}

\author{
(Farming, Income and Welfare OF Coffee Farmers in Gunung Terang Village, Air Hitam Subdistrict of \\ West Lampung Regency)
}

Rafika Tania, Sudarma Widjaya, Ani Suryani

Jurusan Agribisnis, Fakultas Pertanian, Universitas Lampung, Jl. Prof. Dr. Soemantri Brodjonegoro No. 1 Bandar Lampung 35141, Telp. 082178774630, e-mail: rafikatania42@gmail.com

\begin{abstract}
The purposes of this research were to analyze the level of household income and the welfare of coffee farmers in Gunung Terang Village, Air Hitam District, West Lampung Regency. This research location was chosen purposively in Gunung Terang Village, Air Hitam District, West Lampung Regency. The research was conducted by survey method. Data collection was carried out in October 2017 until November 2017. The sample size was 40 coffee farmers who were drawn by simple random sampling technique. The analysis used analysis of farm income and household welfare according to Sayogyo criteria. The results of this study indicate that the average household income of coffee farmers in Gunung Terang Village, Air Hitam Subdistrict, West Lampung Regency were relatively high and the welfare of coffee farmer households based on Sayogyo criteria were categorize as prosperous.
\end{abstract}

Key words: coffee, income, prosperity

\section{PENDAHULUAN}

Indonesia terkenal dengan sebutan negara agraris, yang ditunjukkan oleh luas lahan yang digunakan untuk pertanian. Dari seluruh luas lahan yang ada di Indonesia, 82,71 persen digunakan untuk pertanian (Badan Pusat Statistik 2015). Kontribusi sektor pertanian dapat dilihat pada Produk Domestik Bruto (PDB) sektor pertanian tahun 2014 sampai dengan 2015 yang mengalami pertumbuhan sekitar 3,02 persen dan PDB atas dasar harga berlaku sebesar Rp361,4 triliun. Sektor pertanian menjadi sektor unggulan dalam menyusun strategi pembangunan nasional.

Kopi merupakan komoditas unggulan dalam subsector perkebunan. Kopi merupakan produk yang mempunyai peluang pasar yang baik di dalam negeri maupun luar negeri. Sebagian besar produksi kopi Indonesia merupakan komoditas perkebunan yang diekspor ke pasar dunia. Menurut data statistik International Coffee Organization (ICO) tahun 2015, Indonesia merupakan negara eksportir kopi ke-tiga di dunia. Kontribusi nilai komoditi kopi terhadap perekonomian Indonesia dapat dilihat dari volume (jumlah) ekspor dan nilai ekspor kopi tersebut.

Perkebunan kopi yang umumnya didominasi oleh perkebunan rakyat kurang dikelola dengan baik. Hal ini tentunya membawa konsekuensi terhadap mutu dan jumlah produksi kopi yang dihasilkan untuk ekspor (Sutrisno 2012).

Menurut Badan Pusat Statistik Lampung (2015) diketahui bahwa produksi dan produktivitas kopi Indonesia dari tahun 2011 sampai tahun 2015 ratarata adalah $672.682,4$ ton dan 0,53 ton per hektar dan masih sangat rendah jika dibandingkan dengan potensinya ( 1,2 ton per hektar). Kopi tetap menjadi komoditas unggulan pertanian di Provinsi Lampung disusul lada hitam, udang (segar/olahan) dan coklat.

Perubahan produksi untuk ekspor dari komoditi kopi mempengaruhi nilai ekspor pertanian secara keseluruhan di Provinsi Lampung. Nilai ekspor kopi mengalami peningkatan sebesar 52, 94 persen dari US\$ 394,95 persen juta pada tahun 2011 menjadi US\$ 604,03 juta pada tahun 2015. Kopi di Provinsi Lampung pada umumnya adalah kopi jenis robusta. Perkebunan kopi di dataran tinggi Lampung sebagian besar adalah perkebunan rakyat, khususnya di daerah Lampung Barat, Tanggamus dan Lampung Utara (Badan Pusat Statistik Provinsi Lampung 2015). Kabupaten Lampung Barat merupakan daerah yang potensial untuk pertanian. Komoditas pertanian terbesar di kabupaten ini adalah kopi, yang merupakan subsektor perkebunan. Kopi tersebut merupakan komoditi unggulan Kabupaten Lampung Barat. Pada tahun 2015, Kabupaten Lampung Barat 
memberi kontribusi sebesar 40 persen (61.807 ton) terhadap produksi kopi Lampung. Luas perkebunan kopi di Lampung Barat adalah 60.382 hektar kopi robusta, dan 5 hektar kopi arabika (BPS Provinsi Lampung 2015).

Kabupaten Lampung Barat merupakan wilayah yang memiliki potensi kopi terbesar di Provinsi Lampung dengan luas lahan mencapai 60.382 ha dan produktivitas mencapai 1,02 ton per hektar. Produktivitas kopi di Provinsi Lampung masih kategori rendah (sebesar 0,88 ton per hektar) jika dibandingkan dengan potensi idealnya 1,2 ton per hektar (BPS Provinsi Lampung 2015).

Sehubungan dengan hal tersebut dilakukan penelitian mengenai analisis usahatani, pendapatan dan kesejahteraan petani kopi di Lampung Barat. Tujuan dari penelitian ini adalah untuk menganalisis tingkat pendapatan rumah tangga petani kopi di Kabupaten Lampung Barat, dan menganalisis tingkat kesejahteraan petani kopi di Kabupaten Lampung Barat.

\section{METODE PENELITIAN}

Metode penelitian dilakukan dengan metode survey dengan lokasi penelitian di Kabupaten Lampung Barat, Kecamatan Air Hitam Desa Gunung Terang. Pemilihan lokasi dilakukan secara sengaja (purposive), dengan pertimbangan bahwa kecamatan tersebut merupakan sentra produksi dan memiliki luas lahan kopi yang cukup luas di Kabupaten Lampung Barat. Pengumpulan data penelitian dilakukan pada bulan OktoberNovembaer 2017. Data yang digunakan adalah data primer dan data sekunder. Data primer diperoleh melalui teknik wawancara langsung dengan petani berdasarkan daftar pertanyaan (kuisioner) yang telah disiapkan. Data sekunder diperoleh dari literatur dan laporan instansi terkait sesuai dengan tujuan penelitian.

Responden pada penelitian ini yaitu petani kopi di Desa Gunung Terang Kabupaten Lampung Barat. Populasi sasaran pada penelitian ini adalah petani kopi yang aktif sebanyak 158 orang. Petani kopi memiliki karakteristik luas lahan yang bervariasi dan usia tanaman kopi rata-rata $>8$ tahun. Penentuan jumlah sampel pada penelitian ini, merujuk pada teori Isaac dan Michael dalam Sugiarto (2003) adalah sebagai berikut :

$\mathrm{n}=\frac{\mathrm{NZ}^{2} \mathrm{~S}^{2}}{\mathrm{Nd}^{2}+\mathrm{Z}^{2} \mathrm{~S}^{2}}$
Keterangan:

$\mathrm{n}$ : Ukuran sampel

$\mathrm{N}$ : Ukuran Populasi

$S^{2}:$ Varian Sampel $(5 \%=0,05)$

$\mathrm{Z}$ : Tingkat kepercayaan $(90 \%=1,64)$

d : Derajat penyimpangan $(5 \%=0,05)$

Berdasarkan rumus Issac dan Michael dalam Sugiarto (2003), diperoleh jumlah sampel sebagai berikut :

$\mathrm{n}=\frac{158 \times 1,64^{2} \times 0,05}{158 \times 0,05^{2}+1,64^{2} \times 0,05}=40$

Berdasarkan hasil perhitungan diperoleh jumlah responden sebanyak 40 petani. Sebaran jumlah sampel menurut luas lahan kopi dilakukan di Desa Gunung Terang Kecamatan Air Hitam Kabupaten Lampung Barat. Responden yang telah diperoleh kemudian dipilih secara acak sederhana (simple random sampling) yang dilakukan dengan cara diundian.

Pendapatan usahatani kopi dalam penelitian ini adalah nilai yang diperoleh dari produk total dikalikan dengan harga jualnya di tingkat petani dikurangi biaya. Berdasarkan Rumus Soekartawi (1995) persamaan pendapatan adalah :

$\pi=\mathrm{Y} \cdot \mathrm{Py}-{ }_{\Sigma} \mathrm{Xi} \cdot \mathrm{Pxi}$

Keterangan :

$\pi=$ Pendapatan Usaha Tani

$\mathrm{Y}=$ Jumlah produksi kopi

$\mathrm{Py}=$ Harga per satuan produksi kopi $(\mathrm{Rp} / \mathrm{Kg})$

$\mathrm{Xi}=$ Faktor produksi usahatani kopi $(\mathrm{Xi}=1,2,3 \ldots)$

Pxi $=$ Harga faktor produksi ke $\mathrm{i}(\mathrm{Rp})$

$\mathrm{Y}=$ Jumlah produksi kopi $(\mathrm{kg})$

$\mathrm{Py}=$ Harga per satuan produksi kopi $(\mathrm{Rp} / \mathrm{Kg})$

$\mathrm{Xi}=$ Faktor produksi usahatani kopi $(\mathrm{Xi}$ $=1,2,3, \ldots . . n)$

Pxi $=$ Harga faktor produksi ke i $(\mathrm{Rp})$

Penerimaan usahatani kopi per satuan biaya yang dikeluarkan digunakan indikator Revenue Cost Ratio (R/C). R/C merupakan perbandingan antara penerimaan total usahatani dengan biaya total yang dikeluarkan selama proses produksi berlangsung. $\mathrm{R} / \mathrm{C}$ juga menunjukkan berapa besar penerimaan yang akan diperoleh dari setiap rupiah yang dikeluarkan dalam produksi. Dengan kata lain, analisis rasio penerimaan atas biaya produksi dapat digunakan untuk mengukur tingkat keuntungan kegiatan usahatani. Artinya, dari angka rasio penerimaan atas biaya tersebut dapat diketahui 
apakah suatu usahatani menguntungkan atau tidak. Nilai nisbah penerimaan dan biaya dapat diperoleh dari rumus :

$\mathrm{R} / \mathrm{C}=\frac{\mathrm{TR}}{\mathrm{TC}}$

\section{Keterangan}

$\mathrm{TR}=$ Total Revenue $($ Penerimaan total $)$

$\mathrm{TC}=$ Total Cost (Biaya total $)$

Pengambilan keputusan adalah :

(a) Jika R/C > 1, maka usahatani yang dilakukan menguntungkan, karena penerimaan lebih besar dari biaya total.

(b) Jika R/C <1, maka usahatani yang dilakukan tidak menguntungkan, karena penerimaan lebih kecil dari pada biaya total.

(c) Jika $\mathrm{R} / \mathrm{C}=1$, maka usahatani yang dilakukan tidak menguntungkan dan tidak juga merugi (impas), karena penerimaan total sama dengan biaya total.

\section{Analisis Pendapatan Rumah Tangga Petani Kopi}

Analisis kuantitatif juga digunakan untuk mengukur pendapatan total rumah tangga yang diperoleh dari pendapatan total usahatani dan pendapatan total non usahatani. Perhitungan pendapatan rumah tangga petani kopi dapat dituliskan sebagai berikut :

$\begin{aligned} \text { Prt }= & \mathrm{P}_{\text {on farm (ustan kopi) }}+\mathrm{P}_{\text {on farm (ustan non kopi) }}+\mathrm{P}_{\text {off farm }} \\ & +\mathrm{P}_{\text {non farm }} \ldots \ldots \ldots \ldots \ldots \ldots \ldots \ldots \ldots \ldots \ldots \ldots \ldots \ldots \ldots \ldots \ldots \ldots \ldots \ldots \ldots \ldots \ldots \ldots \ldots\end{aligned}$

Keterangan :

Prt = Pendapatan rumah tangga petani kopi per tahun

$\mathrm{P}$ on farm $_{\text {(usahatani kopi) }} \quad=$ Pendapatan usahatani kopi

P on farm $_{\text {(usahatani non kopi) }}=$ Pendapatan usahatani selain kopi

$\mathrm{P}$ off farm = Pendapatan non

$\mathrm{P}$ non farm = Pendapatan dari luar pertanian

\section{Analisis Tingkat Kesejahteraan}

Analisis tingkat kesejahteraan diukur melalui pendekatan pengeluran rumah tangga dan diklarifikasikan dengan pendekatan berdasarkan teori Sajogyo (1997) .

\section{a. Definisi dan Perhitungan Pengeluaran Rumah Tangga}

Perhitungan pengeluaran rumah tangga berdasarkan kriteria Sajogyo (1997) dibagi menjadi pegeluaran pangan dan non pangan dilakukan dengan cara menghitung kebutuhan harian, mingguan, dan bulanan. Total pengeluaran rumah tangga dapat diformulasikan sebagai :

$$
\mathrm{Ct}=\mathrm{Cp}_{\mathrm{i}}+\mathrm{Cnp} \text {, }
$$

Keterangan :

$\mathrm{Ct}=$ Total pengeluran rumah tangga $=1,2,3$, ......., $n$

$\mathrm{n} \quad=$ Pengeluaran lainnya, selain pengeluaran pangan dan non pangan

$\mathrm{C}_{\mathrm{p}_{i}}=$ Pengeluaran untuk pangan, dengan rumus $\mathrm{Cp}=\mathrm{Cp} 1+\mathrm{Cp} 2+\mathrm{Cp} 3+\mathrm{Cp} 5+\mathrm{Cpn} . . .(6)$

$\mathrm{C}_{\mathrm{p}} 1=$ Pengeluaran untuk padi-padian

$\mathrm{C}_{\mathrm{p}} 2=$ Pengeluaran untuk minyak dan lemak

$\mathrm{C}_{\mathrm{p}} 3=$ Pengeluaran untuk pangan hewani

$\mathrm{C}_{\mathrm{p}} 4=$ Pengeluaran untuk sayur-sayuran

$\mathrm{C}_{\mathrm{p}} 5=$ =Pengeluaran untuk buah-buahan

$\mathrm{C}_{\mathrm{pn}}=$ Pengeluaran lainnya

$\mathrm{C}_{n p_{i}}=$ Pengeluaran untuk nonpangan, dengan rumus :

Cnp $=$ Cnp1 + Cnp2 + Cnp3 + Cnp4 +

Cnpn..........................(7)

$\mathrm{C}_{\mathrm{np}} 1=$ Pengeluaran untuk bahan bakar

$\mathrm{C}_{\mathrm{np}} 2=$ Pengeluaran untuk aneka barang/jasa

$\mathrm{C}_{\mathrm{np}} 3=$ Pengeluaran untuk pendidikan

$\mathrm{C}_{\mathrm{np}} 4=$ Pengeluaran untuk kesehatan

$\mathrm{C}_{\mathrm{np}} 5=$ Pengeluaran untuk listrik

$\mathrm{C}_{\text {npn }}=$ Pengeluaran 1 ainnya

Pengeluaran rumah tangga per kapita per tahun adalah total pengeluaran rumah tangga usahatani kopi, baik pengeluaran untuk pangan maupun nonpangan dalam sebulan, yang dikonversi ke tahun dan dibagi dengan jumlah tanggungan rumah tangga (Sajogyo 1997).

\section{b. Pendekatan Berdasarkan Teori Sajogyo}

Analisis tingkat pengeluaran per kapita per tahun tiap keluarga digunakan untuk mengetahui tingkat pendapatan petani kopi, yaitu total pendapatan keluarga dari usahatani kopi, dan dari luar usahatani kopi. Pendapatan ini kemudian dikonversi ke dalam ukuran pendapatan setara beras dalam satuan kilogram untuk melihat tingkat kemiskinan 
(Sayogyo 1997). Secara matematis tingkat pendapatan per kapita per tahun tiap keluarga dan tingkat pendapatan per kapita per tahun tiap keluarga setara beras dapat dirumuskan sebagai:

$\pi /$ kapita/th $(\mathrm{Rp})=\frac{\pi(R p)}{\Sigma \text { Anggota Keluarga }}$

$\pi /$ kapita/setara beras $(\mathrm{kg})=\frac{\pi / \text { kapita } / \operatorname{th}(R p)}{\text { Harga Beras }} \ldots$

Perhitungan kemiskinan menurut Sayogyo (1997) didasarkan pada besarnya pengeluaran per kapita per tahun yang diukur dengan harga beras setempat. Kriteria perhitungan tersebut adalah apabila pengeluaran per kapita per tahun setara beras :

(1) $<180 \mathrm{~kg}$ yaitu paling miskin

(2) $180-240 \mathrm{~kg}$ yaitu miskin sekali

(3) $240-320 \mathrm{~kg}$ yaitu miskin

(4) $320-480 \mathrm{~kg}$ yaitu nyaris miskin

(5) $480-960 \mathrm{~kg}$ yaitu cukup

$>960 \mathrm{~kg}$ yaitu hidup layak

\section{HASIL DAN PEMBAHASAN}

Karakteristik responden dapat dilihat dari umur, tingkat pendidikan, lama berusahatani kopi, jumlah angota keluarga, luas lahan usahatani kopi, status kepemilikan, dan pekerjaan sampingan. Umur responden berkisar antara 27 - 65 dengan rata-rata umur 49 tahun. Menurut Mantra (2004) usia produktif berkisar 15 sampai 64 tahun, oleh karna itu sebagian besar petani kopi berada pada usia produktif. Jika dilihat dari tinggat pendidikan responden, maka tingkatan terbanyak berada pada tingkat pendidikan SD (Sekolah Dasar sebanyak 21 orang dengan persentase 52,50 persen. Pengalaman petani gunung terang dalam berushatani cukup lama berkisar angtara 30 sampai 42 tahun dengan persentase 45,00 persen. Rata-rata jumlah anggota keluarga petani gunung terang berada pada kisaran 2-3 orng dengan persentase sebesar 62,50 persen. Luas lahan kopi yang di budidayakan oleh petani kopi di Desa Gunung Terang tergolong sempit, karena sebagian besar kepemilikan luas lahan kopi berkisar antara 1,00-2, ha dengan persentase

72,50 persen. Status kepemilikan lahan 40 orang petani kopi merupakan lahan milik sendiri. Pekerjaan sampingan yang dilakukan petani kopi sebagian berasal dari berdagang, ojek, PNS, dan buruh bangunan.

\section{Penggunaan Input}

Penggunaan pupuk pada tanaman kopi tentu sangat penting dalam proses budidaya, apalagi jika petani menginginkan hasil produksi kopi yang tinggi maka diperlukan peggunaan pupuk yang tinggi pula. Biaya pupuk yang dikeluarkan petani kopi di Desa Gunung Terang sebanyak Rp4.460.812,50, yang terdiri dari pupuk urea, phonska, kandang, TSP, dolomit, dan mutiara. Biaya pupuk yang paling banyak digunakan oleh petani kopi adalah biaya pupuk urea yaitu sebanyak Rp1.341.281,25.

Pestisida adalah bahan yang digunakan untuk membasmi organisme pengganggu tanaman. Hal ini dilakukan petani untuk mempersingkat waktu dan penggunaan tenaga kerja. Herbisida merupakan bahan kimia yang digunakan untuk membasmi gulma atau rumput yang ada di sekitar tanaman kopi. Petani kopi rata-rata sudah menggunakan obat-obatan jenis pestisida dan herbisida dengan tujuan agar produksi yang dihasilkan maksimal sesuai dengan yang diharapkan oleh petani. Biaya penggunaan obatobatan yang paling banyak digunakan petani kopi adalah herbisida sebanyak Rp1.149.750,00. Herbisida banyak digunakan karena gulma atau rumput yang ada di sekitar tanaman kopi sangat banyak dan apabila tidak diatasi maka akan berpengaruh terhadap produksi kopi yang dihasilkan. Penggunaan dan biaya obat-obatan dapat dilihat pada Tabel 1.

\section{Analisis Pendapatan Rumah Tangga Petani}

\section{Pendapatan Usahatani Kopi (On farm)}

Analisis pendapatan dapat digunakan untuk menilai apakah usahatani tersebut layak atau tidak untuk diusahakan. Penerimaan merupakan hasil kali antara produksi dan harga. Biaya produksi yang dikeluarkan oleh petani kopi di Desa Gunung Terang terdiri dari dua jenis biaya, yaitu biaya tunai dan biaya diperhitungkan. Biaya tunai merupakan biaya yang secara tunai atau secara langsung dikeluarkan oleh petani kopi untuk memperlancar kegiatan produksi. Biaya tunai tersebut berasal dari biaya pupuk, pestisida, herbisida, TKLK, angkut, dan rokok. 
Tabel 1. Jumlah dan biaya penggunaan pestisida dan herbisida pada usahatani kopi di Desa Gunung Terang tahun 2017

\begin{tabular}{ccccc}
\hline \multirow{2}{*}{ No. } & \multirow{2}{*}{ Jenis Obat-Obatan } & \multicolumn{2}{c}{ Rata-Rata penggunaan dan harga } & \multirow{2}{*}{ Biaya (Rp) } \\
\cline { 2 - 4 } & & Jumlah (liter) & Harga (Rp) & \\
\hline 1. & Pestisida & 9,78 & $56.964,29$ & $558.750,00$ \\
2. & Herbisida & 19,95 & $57.700,00$ & $1.149 .750,00$ \\
\hline \multicolumn{2}{l}{ Total Biaya } & & & $1.708 .500,00$ \\
\hline
\end{tabular}

Tabel 2. Pendapatan usahatani kopi

\begin{tabular}{|c|c|c|c|c|}
\hline No. & Uraian & Satuan & $\begin{array}{c}\text { Rata-rata } \\
\text { per } 2,19 \text { ha }\end{array}$ & $\begin{array}{c}\text { Rata-rata } \\
\text { per ha }\end{array}$ \\
\hline 1. & Produksi & $\mathrm{kg}$ & $3.222,50$ & $1.471,46$ \\
\hline 2. & Penerimaan & $\mathrm{Rp}$ & $73.473 .000,00$ & $33.549 .315,07$ \\
\hline 3. & Biaya tunai & $\mathrm{Rp}$ & $9.043 .260,21$ & $4.129 .345,56$ \\
\hline \multirow[t]{4}{*}{4.} & Biaya diperhitungkan & & & \\
\hline & Biaya variable & $\mathrm{Rp}$ & $17.975 .750,00$ & $8.208 .105,03$ \\
\hline & Biaya tetap & $\mathrm{Rp}$ & $899.931,96$ & $410.927,84$ \\
\hline & Total biaya & $\mathrm{Rp}$ & $27.918 .842,17$ & $12.748 .375,42$ \\
\hline \multirow[t]{3}{*}{5.} & Pendapatan & & & \\
\hline & Pendapatan Atas Biaya Tunai & $\mathrm{Rp}$ & $64.429 .739,79$ & 29.419.972,51 \\
\hline & Pendapatan Atas Biaya Total & $\mathrm{Rp}$ & $45.554 .057,83$ & $20.800 .939,65$ \\
\hline \multirow[t]{3}{*}{6.} & R/C Ratio & & & \\
\hline & R/C Ratio Atas Biaya Tunai & & 8,12 & 8,12 \\
\hline & R/C Ratio Atas Biaya Total & & 2,63 & 2,63 \\
\hline
\end{tabular}

Produksi adalah besarnya output yang dihasilkan dari suatu kegiatan usahatani kopi pada periode waktu tertentu. Tabel 2 menunjukkan pendapatan usahatani kopi. Produksi rata-rata petani kopi responden di Desa Gunung Terang sebesar $3.222,50 \mathrm{~kg}$ per tahun. Penerimaan usahatani kopi merupakan hasil kali dari banyaknya kopi yang dihasilkan petani dengan harga jual kopi per $\mathrm{kg}$. Harga rata-rata kopi per $\mathrm{kg}$ yang diterima petani responden sebesar Rp22.800,00 per kg, sehingga penerimaan rata-rata petani responden sebesar Rp73.473.000,00.

Pendapatan yang diperoleh petani dari usahatani kopinya tentu dimanfaatkan kembali untuk merawat tanaman kopi mereka, sedangkan untuk pendapatan per bulannya diperoleh petani dari tanaman holtikultura. Petani kopi memanfaatkan pendapatan dari usahatani kopi untuk membeli input seperti pupuk dan obat-obatan, membayar tenaga kerja, sewa lahan, dan biaya angkut. Input tersebut digunakan untuk memperlancar kegiatan usahatani kopi agar produksi yang dihasilkan maksimal.

Berdasarkan hasil penelitian dapat dilihat bahwa usahatani kopi di Desa Gunung Terang berdasarkan luasan lahan 2,19 ha dan per hektar sudah menguntungkan dan layak untuk diusahakan dengan RC $>1$. Hasil penelitian ini sejalan dengan penelitian yang dilakukan Lestari, Hasyim, dan
Kasymir (2017) yang menunjukkan bahwa usahatani kopi di Kecamatan Pulau Panggung Kabupaten Tanggamus memiliki R/C > 1 yang berarti usahatani kopi tersebut layak untuk diusahakan dan menguntungkan. Hasil penelitian Putri (2015) juga menunjukkan bahwa usahatani kopi di Kabupaten Lampung Barat menguntungkan atau layak diusahakan karena $\mathrm{R} / \mathrm{C}>1$.

Selain usahtani kopi sebagai sumber pendapatan utama petani kopi di Desa Gunung Terang, sumber lain pendapatan tambahan petani juga berasal dari usahatani lainnya. Komoditas yang biasa dibudidayakan petani beragam mulai dari komoditas pisang, cabai, lada, sawi, terong, singkong dan labusiem. Hasil yang diperoleh dari komoditas-komoditas tersebut sebagian digunakan untuk konsumsi rumah tangga petani sendiri, dan sisanya dijual sebagai tambahan pendapatan rumah tangga. Tabel 3 menunjukkan bahwa sumber pendapatan tambahan petani kopi di Desa Gunung Terang banyak diperoleh petani dari komoditas lada yaitu sebesar 65,1 persen, kemudian komoditas pisang dengan persentase sebesar 21,4 persen, dan komoditas cabai sebesar 12,5 persen. Rata-rata pendapatan usahatani di luar usahatani kopi adalah Rp1.819.125,00 per tahun. 
Tabel 3. Rata-rata pendapatan On Farm

\begin{tabular}{clrc}
\hline No & Komoditas & Pendapatan $(\mathrm{Rp} / \mathrm{thn})$ & Persentase $(\%)$ \\
\hline 1 & Pisang & $389.875,00$ & 21,4 \\
2 & Cabai & $226.750,00$ & 12,5 \\
3 & Lada & $1.184 .375,00$ & 65,1 \\
4 & Sawi & $2.500,00$ & 0,1 \\
5 & Terong & $1.125,00$ & 0,1 \\
6 & Singkong & $5.750,00$ & 0,3 \\
7 & Labusiem & $8.750,00$ & 0,5 \\
\hline \multicolumn{2}{l}{ Total } & $1.819 .125,00$ & $100,0 \%$ \\
\hline
\end{tabular}

\section{Pendapatan di Luar Pertanian (Non-Farm)}

Pendapatan rumah tangga petani kopi juga berasal dari luar sektor pertanian seperti pedagang, PNS, ojek dan tukang bangunan. Setiap kegiatan memberikan kontribusi yang berbeda terhadap total pendapatan rumah tangga. Pendapatan rumah tangga petani kopi dari kegiatan luar usahatani (non farm) sebesar Rp5.025.000,00 per tahun. Persentase pendapatan terbesar berasal dari PNS yaitu Rp2.250.000,00 per tahun atau sebesar 44,78 persen dari total rata-rata pendapatan non farm. Tabel pendapatan non farm dapat dilihat pada Tabel 4.

\section{Pendapatan rumah tangga petani kopi}

Pendapatan rumah tangga petani kopi di Desa Gunung Terang berasal dari pendapatan on farm dan non farm yang dapat dilhat pada Tabel 5 . Sektor yang memiliki kontribusi terbesar terhadap pendapatan rumah tangga petani kopi di Desa Gunung Terang adalah sektor on farm. Hal ini selaras dengan penelitian Mardiana, Abidin dan Soelaiman (2014) bahwa pendapatan on farm lebih besar kontribusinya terhadap pendapatan rumah tangga petani dibandingkan dari sektor non farm.

\section{Tingkat Kesejahteraan Rumah Tangga Petani dengan Pendekatan Sajogyo (1997)}

Tingkat kesejahteraan rumah tangga petani kopi di Desa Gunung Terang diukur dengan metode yang ditetapkan Sajogyo (1997). Menurut Sajogyo (1997), pengeluaran rumah tangga per kapita per tahun adalah total pengeluaran rumah tangga petani baik pengeluaran untuk pangan maupun non pangan dalam setahun dibagi jumlah tanggungan rumah tangga.
Tabel 4. Rata-rata pendapatan usaha non farm tahun 2017 di Desa Gunung Terang

\begin{tabular}{llcrc}
\hline No & $\begin{array}{l}\text { Pekerjaan } \\
\text { Non farm }\end{array}$ & $\begin{array}{c}\text { Jumlah } \\
\text { (Orang) }\end{array}$ & $\begin{array}{r}\text { Rata-Rata } \\
\text { Pendapatan } \\
\text { (Rp/tahun) }\end{array}$ & $\begin{array}{c}\text { Persentase } \\
(\%)\end{array}$ \\
\hline 1. & Pedagang & 7 & $1.020 .000,00$ & 20,30 \\
2. & PNS & 3 & $2.250 .000,00$ & 44,78 \\
3. & Ojek & 4 & $525.000,00$ & 10,45 \\
4. & Tukang & 7 & $1.230 .000,00$ & 24,47 \\
& Bangunan & & $5.025 .000,00$ & 100 \\
\hline
\end{tabular}

Tabel 5. Pendapatan rumah tangga petani kopi di Desa Gunung Terang

\begin{tabular}{lrr}
\hline $\begin{array}{c}\text { Sumber } \\
\text { Pendapatan }\end{array}$ & $\begin{array}{c}\text { Rata-Rata } \\
\text { Pendapatan } \\
\text { (Rp/tahun) }\end{array}$ & $\begin{array}{c}\text { Kontribusi } \\
\text { Terhadap } \\
\text { Pendapatan } \\
\text { Rumah Tangga (\%) }\end{array}$ \\
\hline On farm & $22.260 .064,65$ & 81,60 \\
Non farm & $5.025 .000,00$ & 18,40 \\
\hline
\end{tabular}

Tingkat kesejahteraan rumah tangga diperoleh dari pengeluaran rumah tangga per kapita per tahun. Total pengeluaran rumah tangga kemudian dikonversikan ke dalam ukuran setara beras per kilogram, untuk mengetahui tingkat kemiskinan rumah tangga petani. Ukuran setara beras per kilogram menggunakan harga beras sebesar Rp9.037,50.

Tingkat kesejateraan petani kopi di Desa Gunung Terang dapat digolongkan ke dalam enam golongan. Sebaran golongan tingkat kesejateraan petani pisang di Desa Padang Cermin dapat dilihat pada Tabel 6.

Kategori kesejahteraan petani kopi meliputi kategori nyaris miskin, cukup, dan hidup layak. Petani kopi di Desa Gunung Terang untuk golongan nyaris miskin sebanyak satu orang $(2,50 \%)$, hal ini disebabkan petani tersebut tidak memiliki pekerjaan sampingan, sehingga dapat mempengaruhi pendapatan yang diterima. Semakin besar pendapatan rumah tangga petani maka akan semakin besar juga pengeluaran rumah tangga petani, begitu juga sebaliknya. Kategori cukup sebanyak 37 orang $(92,50 \%)$. Hal ini karena kebanyakan rumah tangga petani responden tidak memiliki terlalu banyak jumlah tanggungan keluarga dan adanya keberagaman sumber pendapatan bagi rumah tangga sehingga pendapatan rumah tangga yang dihasilkan mampu mencukupi katagori hidup layak sebanyak dua orang $(5,00 \%)$. 
Tabel 6. Sebaran golongan tingkat kesejateraan petani kopi di Desa Gunung Terang Kabupaten Lampung Barat

\begin{tabular}{|c|c|c|c|c|}
\hline No. & Golongan & Interval Skor & Jumlah (Orang) & Persentase (\%) \\
\hline 1. & Paling Miskin & $<180 \mathrm{~kg}$ setara beras/tahun & 0,00 & 0,00 \\
\hline 2. & Miskin Sekali & $181-240 \mathrm{~kg}$ setara beras/tahun & 0,00 & 0,00 \\
\hline 3. & Miskin & $241-320 \mathrm{~kg}$ setara beras/tahun & 0,00 & 0,00 \\
\hline 4. & Nyaris Miskin & $321-480 \mathrm{~kg}$ setara beras/tahun & 1,00 & 2,50 \\
\hline 5. & Cukup & 481 - $960 \mathrm{~kg}$ setara beras/tahun & 37,00 & 92,50 \\
\hline 6. & Hidup Layak & $>960 \mathrm{~kg}$ setara beras/tahun & 2,00 & 5,00 \\
\hline Cotal & & & 40,00 & 100 \\
\hline
\end{tabular}

Petani yang hidup layak diidenfikasi sebagai petani yang memiliki keberagaman usaha dan rumah tangganya seperti petani yang memiliki pekerjaan di luar aktifitas pertanian atau petani yang mampu menambah pendapatan dari luar usahtani kopi.

Hasil penelitian ini berbeda dengan penelitian Putri (2015) yang menunjukkan bahwa tingkat kesejahteraan petani kopi di Kabupaten Lampung Barat berdasarkan kriteria Sayogjo masuk dalam kategori hidup layak, sedangkan pada penelitian ini sebesar 92,50 persen petani responden masuk dalam kategori cukup.

Petani kopi di Desa Gunung Terang masuk dalam kategori cukup, karena total pengeluaran per tahun sangat besar dan responden tidak memiliki banyak jumlah tanggungan keluarga serta adanya keberagaman sumber pendapatan bagi rumah tangga sehingga pendapatan rumah tangga yang dihasilkan mampu mencukupi kebutuhan hidup sehari-hari.

Petani kopi di Desa Gunung Terang dalam kategori cukup karena total pengeluaran per tahun cukup besar dan jumlah tanggungan keluarga petani berkisar 2-5 orang, sehingga pengeluaran per kapita per tahun cukup besar dengan harga beras sebesar Rp9.000,00. Petani kopi dalam memenuhi kebutuhan selama setahun telah tercukupi, dan kebutuhan anak-anak mereka juga tercukupi. Pendapatan petani kopi yang diterima apabila dikurangi dengan pengeluaran rumah tangga menyisahkan sedikit pendapatan, walaupun tidak terlalu besar.

Petani kopi di Desa Gunung Terang dalam kategori cukup karena total pengeluaran per tahun sangat sedikit, sehingga pengeluaran per kapita per tahun sangat kecil hanya sebesar Rp8.568.000,00, dengan harga beras sebesar Rp9.000,00. Hal ini tidak selaras dengan penelitian Halim, Salimah dan Satia (2011) dikarenakan dalam menilai petani di desa tersebut rata-rata memiliki tingkat kemiskinan yang tinggi dilihat dari pengukuran menurut Sayogyo.

\section{KESIMPULAN}

Rata-rata pendapatan rumah tangga petani kopi di Desa Gunung Terang Kabupaten Lampung Barat tergolong tinggi yaitu sebesar Rp27.265.064,65 dan Petani kopi di Desa Gunung Terang Kabupaten Lampung Barat sudah masuk kategori sejahtera berdasarkan kriteria Sayogyo (1997) dan BPS (2007).

\section{DAFTAR PUSTAKA}

Badan Pusat Statistik Provinsi Lampung. 2007. Indikator Kesejahteraan Rakyat Provinsi Lampung. Lampung.

Badan Pusat Statistik Provinsi Lampung. 2015. Kabupaten Lampung Barat Dalam Angka. Provinsi Lampung. Bandar Lampung.

Ditjenbun Direktorat Jenderal Perkebunan. 2015. Statistik Perkebunan Indonesia. Jakarta. Ditjenbunhttp://ditjenbun.deptan.go.id/ statis -29 pdb.html. [5 Februari 2017].

Halim, Salimah dan Satia. 2011. Distribusi pendapatan dan tingkat kemiskinan Petani kopi arabika di Desa Tanjung Beringin Kecamatan Sumbul Kabupaten Dairi.1-11. http://down load.portalgaruda.org/article.php?article $=58$ 800\&val=4143. [21 Januari 2017].

International Coffee Organization. 2006. Coffee Statistics. International Coffee Orga nization, London.http://International. Coffee.Organi zation.blog.go.id/. [02 Februari 2017].

Lestari O, AI Hasyim, E Kasymir. 2017. Analisis usahatani dan efisiensi pemasaran kopi (Coffea Sp) Di Kecamatan Pulau Panggung Kabupaten Tanggamus. JIIA, 5 (1):1-8. http://jurnal.fp.unila.ac.id/index.php/JIA/ar ticle/view/1668. [28 November 2018].

Mantra IB. 2004. Demografi Umum. Penerbit Pustaka Pelajar. Yogyakarta.

Mardiana, Abidin, dan Soelaiman. 2014. Pendapatan dan kesejahteraan petani karet 
rakyat di Kecamatan Bumi Agung Kabupaten Waykanan. JIIA, 2 (3):1-7. http://jurnal.fp. unila.ac.id/index.php/JIIA/article/view/806/73 6. [ 28 November 2018].

Putri MJ. 2015. Analisis Pendapatan dan Tingkat Kesejahteraan Rumah Tangga Petani Kopi di Kabupaten Lampung Barat. Skripsi. Universitas Lampung. Bandar Lampung.

Sayogyo. 1997. Garis Kemiskinan dan Kebutuhan Minimum Pangan. LPSB IPB. Bogor. http://www.akademia.edu/21155933/analisis pendapatan dan kesejahteraan. [ 24 Desember 2016].

Soekartawi. 1995. Analisis Usaha Tani. Jakarta. UI Press.

Sugiarto. 2003. Teknik Sampling. PT Gramedia Pustaka Utama. Jakarta.

Sutrisno. 2012. Manajemen Keuangan Teori, Konsep dan Aplikasi. EKONISIA. Yogyakarta. 